\title{
Inter- Union Rivalry, Legitimacy and Union Influence on Shop-Floor Industrial Relations in Zimbabwe's Urban Councils
}

\author{
Farai Ncube \\ Faculty of Management \& Law, School of Economic and Management, University of Limpopo, Polokwane, South Africa \\ Email address: \\ fncube@msu.ac.zw

\section{To cite this article:} \\ Farai Ncube. Inter- Union Rivalry, Legitimacy and Union Influence on Shop-Floor Industrial Relations in Zimbabwe's Urban Councils. \\ International Journal of Economics, Finance and Management Sciences. Vol. 4, No. 6, 2016, pp. 362-368. \\ doi: $10.11648 /$ j.ijefm.20160406.18
}

Received: July 21, 2016; Accepted: October 31, 2016; Published: December 5, 2016

\begin{abstract}
The article examines how inter-union rivalry affects shop-floor industrial relations in Zimbabwe's urban councils. In essence inter union rivalry destroy union solidarity and creates unnecessary competition which end up destroying effective shop-floor worker representation. In an attempt to garner membership and quest to claim legitimacy, the study reveals strategies adopted by unions, which further creates a huge rift among them. This massive competition to enhance trade union density results in unions channelling more energy on fighting each other and in the process abandoning their role of advancing worker interest. Resultantly findings reveal a weakened state of worker representation and an invisible managerial hand in trade union affairs extending the managerial prerogative. Political interference and dominance is equally witnessed. The paper recommends unity of purpose in representing mutual employee interests, as well as minimal political tolerance on union business, unconditional collaboration and willingness to compromise.
\end{abstract}

Keywords: Industrial Relation, Legitimacy, Inter-Union Rivalry, Trade Unions, Urban Councils, Zimbabwe

\section{Introduction}

Simple logic suggests that trade unionism thrives on membership; with low union density union power is diluted and compromised. Unions obviously do all they can to increase their membership, which sparks inter-union rivalry [1]. Without enough members a union will always lack legitimacy to authoritatively represent its members. Resultantly management always take advantage of limited union interference hence at times managers are responsible for either destroying or sabotaging the trade unions directly or indirectly. In organisations with more than one union, trade union rivalry becomes the order of the day. Inter-union rivalry is mainly because of the multiplicity of unions which ultimately cuts at the very root of unionism, weakens the power of collective bargaining, and reduces the effectiveness of workers in securing their legitimate rights [2]. 1n a democracy, political influence of trade unionism cannot be avoided, which further widens and divide trade unions hence adversely affecting effective worker representation [3]. The paper focuses on inter-union rivalry at Gweru town council.

\section{Background}

The study examines three unions embroiled in a dog eat dog situation at one of Zimbabwe Urban Council. The multiplicity of trade unions is a major problem among the trade unions. The situation obtaining at Gweru Urban Council is not peculiar to the council alone but may reflect the reality of trade unionism across all urban councils. The council employs an access of 1179 employees, who are represented by 3 trade unions affiliated to 3 different labour centres. The unions are further divided on political grounds, a situation that is creating a great chasm between them in terms of ideological differences.

Three (3) unions represent worker interest in the local authority. The 3 unions are divided and rooted in different political divides resulting on competition for membership, recognition and legitimacy. The 3 unions involved in the survival of the fittest mode are, the Zimbabwe Urban 
Councils Workers' Union (ZUCWU), the Zimbabwe Rural and Urban Workers Union (ZRUWU) and finally the Water and Allied Workers Union of Zimbabwe (WAWUZ). ZUCWU is affiliated to the Zimbabwe Congress of Trade Union (ZCTU) and therefore labelled an extension of the Movement for Democratic Change (MDC). ZRUWU is affiliated to the Zimbabwe Federation of Trade Unions (ZFTU) and is viewed as an arm of Zimbabwe African
National Union- Patriotic Front (ZANU-PF). WAWUZ is both a union and a federation on its own.

Table 1 bellow depicts union membership from 2009 to 2016. The table obtained from ZUCWU pamphlet suggest that the first union to be registered was ZUCWU in 1981 which enjoyed monopoly till the formation of ZRUWU in 2003 and subsequently the coming in of WAWUZ in 2007.

Table 1. Union Density from 2009 to 2016.

\begin{tabular}{llllll}
\hline Union Name & Year of formation & Membership 2009 & Membership 2013 & Membership 2015 & Membership 2015 \\
\hline ZUCWU & 1981 & 98 & 196 & 469 & 510 \\
ZRUWU & 2003 & 138 & 137 & 138 & 197 \\
WAWUZ & 2007 & 70 & 68 & 48 & 27 \\
\hline
\end{tabular}

Source: ZUCWU 2016 pamphlet

\subsection{Union Rivalry and Party Politics}

Trade unions play a significant role in directly shaping people's working lives today [6]. Unions have a permanent responsibility, both formal and implicit, with regard to their representative role in matters entrusted to them [4]. They are the natural 'vessels' for advancing worker interest without compromise. However Trade unions in Africa have a long tradition of political engagement, beginning with their involvement in the anti-colonial movements through to present day struggles for democracy [7]. While it is an undeniable fact that in most countries unions brought about some economic, political and social betterment of the workers [5] in Zimbabwe the union political alliance is now bedevilling proper worker representation, creating serious shop-floor industrial relation problems. Political affiliations have resulted in massive inter-union rivalry. Unions often cannot make a constructive approach because of intensive inter-union rivalries and multiplicity of unions [3]. Thus there is little doubt that politics matters to unions since the strength of a union is a product of membership, and actual 'clout at the bargaining table and in politics [4].

The relationship between political parties and trade unions can never be underestimated [8]. Trade unions are ideologically and naturally tied to political parties, a situation if not properly monitored can affect adversely effective employee representation as well as spark inter union rivalry within and among organisations. This is in line with the views of [4] who content that trade unionism as a part of Civil Society Organisations (CSO) cannot effectively represent member interest without being politically aligned. Thus trade unionism may be difficult to separate from politics a situation that [5] suggest started during the colonial era.

Union rivalry is equated to union raids, which are viewed as a drain of time and money being far disproportionate to the number of employees involved and therefore creating industrial strain and conflict that do nothing to add to the strength and capabilities of the trade union movement as a whole [10]. Form this angle it is clear that inter-union rivalry breaks the very purpose of the trade unions by weakening the strength of collective bargaining. The state of rivalry between unions can be a potent cause of industrial disputes is not properly checked which may lead to slow growth of trade union movement. Union rivalry is commonly thought to be a waste of union resources, and therefore, suggest that unions have continually attempted to eliminate, or at least reduce, incidences of rivalry, but for the 3 identified unions this seems to be far from the truth [10].

Inter union rivalry seen mainly because of the political outsiders wanting to establish their unions for their own view of increasing their political influence [10]. Inter-union rivalry ultimately cuts at the very root of unionism, weakening the power of collective bargaining, and reducing the effectiveness of workers in securing their legitimate rights. Multiple unionism sometimes is desirable for the democratic health of labour movements, since it encourages health competition and act as a check to the adoption of undemocratic practice, authoritative structures and autocratic leadership [9]. However [9] was quick to point out that in most cases the nature of competition tends to convert itself into a sense of unfair competition resulting in massive interunion rivalry. The rivals destroy the feeling of mutual trust and corporation among leadership.

\subsection{Research Objectives}

The research sought to determine how inter union rivalry affects shop-floor industrial relations.

\section{Methodology}

Primary and secondary sources of data were utilised for data collection. The study was conducted through the use of both questionnaires and interviews with key informants from the two dominant unions, the Zimbabwe Urban Council Worker's Union (ZUCWU) and the Zimbabwe Rural Council Worker's Union (ZRCWU). Given the nature of the study union officials were targeted and selected through the use judgemental sampling technique by focusing on those appropriate to the study. In total 51 union officials, paralegals 
and shop stewards participated in the study. Of the 51 participants 30 belonged to ZUCWU obviously because it had more members hence possessing a bigger committee and 21 respondents were ZRUWU members. Of the 51 combined together $18(35.3 \%)$ were female and 33(64.7\%) male.

\section{Summary of Results}

Table 2 below depict responses to the 5 point likert scale that was utilised for all the 51 respondents who participated in the study. The 5 point likert scale ranged from $1-5$ representing respondent views.

Table 2. Summary of Results

\begin{tabular}{|c|c|c|c|c|c|c|c|c|c|c|c|c|}
\hline & SD -1 & & D-2 & & N-3 & & A-4 & & SA-5 & & Total & \\
\hline & $F$ & $\begin{array}{l}\text { \%freq } \\
\mathrm{N}=51\end{array}$ & $f$ & $\begin{array}{l}\text { \%freq } \\
\mathrm{N}=51\end{array}$ & $f$ & $\begin{array}{l}\text { \%freq } \\
\mathrm{N}=51\end{array}$ & $F$ & $\begin{array}{l}\text { \%freq } \\
\mathrm{N}=51\end{array}$ & $F$ & $\begin{array}{l}\text { \%freq } \\
\mathrm{N}=51\end{array}$ & $\boldsymbol{F}$ & $\begin{array}{l}\% \text { freq } \\
\mathrm{N}=51\end{array}$ \\
\hline $\begin{array}{l}\text { I acknowledge the existence } \\
\text { of union rivalry }\end{array}$ & 4 & 7.8 & 3 & 5.8 & 2 & 3.9 & 12 & 23.5 & 30 & 58.2 & 51 & 100 \\
\hline $\begin{array}{l}\text { Unions are divided on } \\
\text { political grounds }\end{array}$ & 5 & 9.8 & 3 & 5.8 & 1 & 1.9 & 15 & 29.4 & 27 & 52.9 & 51 & 100 \\
\hline $\begin{array}{l}\text { Union membership is based } \\
\text { on political orientation }\end{array}$ & 12 & 23.5 & 7 & 13.7 & 5 & 9.8 & 11 & 21.5 & 16 & 31.3 & 51 & 100 \\
\hline $\begin{array}{l}\text { There is an avenue for union } \\
\text { to collaboration }\end{array}$ & 15 & 29.4 & 10 & 19.6 & 6 & 11.8 & 10 & 19.6 & 10 & 19.6 & 51 & 100 \\
\hline $\begin{array}{l}\text { Management has a hand in } \\
\text { union problems }\end{array}$ & 4 & 7.8 & 4 & 7.8 & 3 & 5.8 & 17 & 33.3 & 23 & 45.0 & 51 & 100 \\
\hline $\begin{array}{l}\text { Inter union rivalry is } \\
\text { adversely affecting workers }\end{array}$ & 7 & 13.7 & 3 & 5.8 & 1 & 1.9 & 21 & 41.1 & 19 & 37.2 & 51 & 100 \\
\hline $\begin{array}{l}\text { Unions are failing to deliver } \\
\text { in the best interest of workers }\end{array}$ & 5 & 9.8 & 7 & 13.7 & 6 & 11.7 & 16 & 31.3 & 17 & 33.3 & 51 & 100 \\
\hline
\end{tabular}

Key: $\mathrm{SD}=$ Strongly Disagree, $\mathrm{D}=$ Disagree, $\mathrm{N}=$ Neutral, $\mathrm{A}=$ Agree, $\mathrm{SA}=$ Strongly Agree

\subsection{Existence of Union Rivalry}

The existence of union rivalry was identified by $58.2 \%$ of the respondents who strongly agreed together with 23.5 who equally felt the existence of union rivalry was very rampant in the local authority. $3.9 \%$ of the respondents were neutral and only 14.2 combined together felt that there was no interunion rivalry. It is therefore clear that the majority of the respondents understood the concept of union rivalry.

\subsection{Reason for Union Rivalry}

$52.9 \%$ of the respondents strongly agreed that unions are divided on political grounds. Their views were echoed by $29.4 \%$ of the respondents who also agreed that politics was at play. Only $1.9 \%$ of the respondents remained neutral and $15.2 \%$ disagreed. The research through interviews established that inter union rivalry was sparked by part politics to which the different union officials are affiliated.

$52 \%$ of ZURWU respondents felt ZUCWU membership rose to 510 after the 2013 parliamentary election which saw the coming in of 10 out of 13 councillors belonging to MDC which ZUCWU members are affiliated to. They explained that this growth was not only attributed to membership drive strategies but largely to politics. ZRUWU respondents went on to explain that given that the council is run by councillors whom $76.9 \%$ of the councillors are MDC members. They claimed that these councillors have power to liaise with HR and employ people loyal to the party as well as advising them to join ZUCWU. ZUCWU dismissed the allegation with costs arguing that their leadership was a mixed bag with representatives affiliated to different political parties. ZRUWU pointed out that in the council it's not about what the union offers but about which political party the union is affiliated to. Because of political patronage and fear of victimisation, any initiative by a union no matter how noble is secondary. Equally in the same vein ZUCWU lamented over this stigmatisation as one of the reasons behind failure to recruit other members sympathetic to ZANU-PF.

As depicted by table 2 above $81.7 \%$ respondents acknowledged the existence of inter union rivalry. Of these respondents $75 \%$ pointed out that union rivalry was fuelled by the desire to control $50 \%$ membership which guarantee autonomy to form a worker's committee and participate in works council to fulfil the requirements of Section 23 (1b) of the Zimbabwe Labour Act Chapter 28.01 which reads,

".... if a trade union is registered to represent the interests of not less than fifty per centum of the employees at the workplace where a workers committee is to be established, every member of the workers committee shall be a member of the trade union concerned."

The section notes that in a situation where there are multiple trade unions in an organisation, for the purposes of forming a workers committee, the union with $50 \%$ majority can form a workers committee (with sole members) and represent all the employees. This then gives the union legimacy to represent the interest of all workers in the process controlling shop-floor industrial relations. Given that to date no union has legitimately exceeded $50 \%$ majority there has been a massive campaign for membership resulting in a massive war to paint each other in the darkest colour. Respondents unanimously agreed to the fact that rivalry was sparked by the need to increase union density and have majority members for each union to stamp authority. Key respondents $(28 \%)$ gave a brief background through an interview. They explained that in 2014 given that there was no union with $50 \%$ members the unions forged an alliance by 
selecting 12 members from the 3 unions who would form a workers committee. Given the numbers each union had ZUCWU was given 8 positions, with ZRUWU 3 positions and WAWUZ having 1 position determined by the level of union density. A temporary workers' committee was set to negotiate member needs. The respondents pointed out that negotiations never materialised as union official (committee members) ended up championing union agenda not what workers wanted which resulted in the intervention of the labour ministry and labour court. The labour court ruling nullified and dissolved the workers committee since members could not work together.

\subsection{Management has a Hand in Union Problems}

$78.3 \%$ respondents agreed and strongly agreed that management had a hand in trade union problems. Through an interview majority $(68 \%)$ of these respondents pointed out that management was responsible for sponsoring a rebel group of workers, which they nicknamed, "Boko Harram", after a Nigerian Terror Group which is against the legitimate Nigerian government policies. Findings suggest that council management in 2015 sponsored a rebel group that de-campaigned all the 3 unions by challenging and questioning the union legitimacy. The respondents claimed that "Boko Haram" was created by management, claiming the members had the support and blessings of the Chamber Secretary Representative. To authenticate their claim they pointed out that "Boko Harram" was given time to address workers each day from morning till afternoon denouncing unions and passing the vote of no confidence on union officials.

To authentic the accusation senior respondents (10\%) pointed out that the very visible hand of management was intending to paralyse unions as well as taint councillors who were recruiting people into unions based on political orientation. The $10 \%$ respondents reiterated that management failed to predict the overall effect of the mobilisation which resulted in workers going on an unofficial strike (against the provision of section 104 of the Zimbabwean Labour Act) from March to April 2015. The strike resulted in all councillors being sacked of by the Local Government Minister on allegations of mismanagement and corruption. Respondents reiterated that after the strike was called off the Labour Ministry demanded a show cause order which "Boko Harram" had no institutional capacity to handle. Considering that people were afraid of lawsuits and possible dismissals all members who participated sought refuge from the very unions which effectively represented them and ended up "nursing a child rape". Thus the managerial desire to divide and rule unions according to the respondents was exposed by that act alone.

Secondly $100 \%$ of ZUCWU members (which is battling to legitimately gain control of the workers committee by virtue of having the $50 \%$ majority) indicated that there was a deliberate managerial plot to derail this process. The union officials indicated that the Council management was reluctant to provide records on the official figures of employees on the union payroll. The ZUCWU leadership felt in principle with 510 members they had the required number to form a workers committee solely composed of their members. The official indicated that the figure they were given of the total staff complement was 1179 inclusive (with line managers) yet the act on section 23 (1) of the Zimbabwe Labour Act Chapter 28.01 which reads:

"...Subject to this Act and any regulations, employees employed by any one employer may appoint or elect a workers committee to represent their interests: Provided that no managerial employee shall be appointed or elected to a workers committee, nor shall a workers committee represent the interests of managerial employees, unless such workers committee is composed solely of managerial employees appointed or elected to represent their interests....."

The union felt that the council management is aware of the provision but very comfortable in the chaos for the purpose of delaying recognising ZUCWU dominance thus deliberately reluctant to release the official figure as a deliberate strategy to avoid dealing with a single union hence promoting the divide and rule strategy to maintain the managerial prerogative..

$100 \%$ respondents from both ZUCWU and ZRUWU revealed that management further created confusion by embracing the skilled as part of management. They reiterated that in a bid to reduce union density management embraced all the skilled workers (drivers, nurses, secretaries, shift supervisors) as managerial employees as a way of stopping them from joining any of the 3 unions but maintaining them on the list of their staff complement. Given the level of union rival senior respondents $(20 \%)$ from the two dominate unions pointed out that the move by management was strategic since the unions would divide and share members but not enough to control $50 \%$ of the workers hence easily returning the managerial prerogative. Increasing the number of line managers on the payroll who legally cannot participate on collective bargaining as "ordinary workers" but including them on the staff complement reduces union density which adversely affects all the 3 unions.

$70.2 \%$ of both ZUCWU and ZRUWU respondents pointed out that management was responsible for worsening the union woes through denying them time to address workers. The respondents pointed out that management denied the union time to attend address its members sighting pressure and volumes of work. Such acts by management create a great chasm between the union and its members.

\subsection{Avenues for Union Collaboration}

From table 2 above a total of $49.0 \%$ of the respondents felt that there was no avenue for union collaboration, with $39.2 \%$ suggesting that union collaboration was possible, only $11.8 \%$ of the respondents were neutral. The $49.0 \%$ respondents suggested that union collaboration was difficult given the membership drive strategies the two dominant unions were using tailor made to paralyse others. 


\subsection{Identified ZUCWU Membership Drives Strategies}

The Union invested a lot in the training of paralegal workers to represent others in disciplinary hearings, negotiations and grievances. The training of paralegal ZUCWU team is facilitated by the University of Zimbabwe Law School. ZUCWU executive reiterated that they have been working in solidarity over the years with other unions and some professional bodies' shaping their strategy and improving their technical competencies in representing and advancing the workers interest. $80 \%$ of the respondents indicated that the union is affiliated to the South African Municipality Worker's Union (SAMWU). They indicated that SAMVU has been funding the auditing of their books of accounts. Notably the union also works with the Public Service International (PSI) which is a Turkey based organisation offering corporate governance training. Given the contribution of these professional bodies ZUCWU has been able to run the union professionally controlling the financials that are needed for smooth operation.

$100 \%$ of the respondents identified that most Zimbabwean urban councils are financially crippled which is affecting their ability to pay employees in time. Given that ZUCWU unlike ZRUWU and WAWUZ whose financials are controlled at their head office, ZUCWU is in total control of $80 \%$ of their subscriptions remitting only $20 \%$ to the head office. ZRUWU senior union officials (10\%) felt that this has given ZUCWU a mileage in advancing its agenda for membership drive through introducing a mutual benefit fund which other unions can't offer. These officials felt ZUCWU was baying membership. $100 \%$ of ZUCWU official pointed out that the union has been able to gunner membership through the creation of the mutual benefit fund for all its members. The fund allows members to borrow funds from the union, which will be paid back after a 30 day period and an interest which ranges from 15 to $30 \%$ of the total amount. The mutual benefit fund provides loans ranging from $\$ 20$ up to $\$ 90$.

Based on the financial muscle $100 \%$ ZUCWU respondents pointed out that they have been able to train shop stewards and all employees on understanding their rights. Through educating them all members has been able to understand crucial rights, ranging from understanding their different types of leave, grievance handling and negotiating skills. Shop stewards have been equally on the forefront on educating workers on their rights at the workplace, understanding the code of conduct, labour laws and other areas of interest. With such education the union has been visible through out as compared to ZRUWU and WAWUZ whose influence has been very minimal.

80.8\% of ZRUWU respondents pointed out that ZUCWU has been very aggressive in marketing itself through offering financial inducements. In the process there have been a lot of defections from WAWUZ and ZRUWU to ZUCWU as evidenced by a sharp increase in union density as shown by table 1 above. The union leadership in a bid to encourage mobilisation for membership came up with a financial inducement incentive scheme. The incentive ranges depending on the number of potential members that one brings into the organisation. If a member brings in 5 members he or she gets $\$ 14$ as an incentive over and above being given transport allowance and food, over and above giving them other benefits such as union regalia (T-shirts, Caps, Calendars, Cups, and Mugs etc). ZRUWU respondents $(100 \%)$ disassociated themselves from such strategies viewing the as (membership buying).

\subsection{ZURWU Membership Drive Supposed Strategies}

$100 \%$ ZURWU leadership reiterated that unlike ZUCWU which had an array of strategies to drive membership at all cost, what they had in-place was a scenario where they thrived to pacify members they already had. $100 \%$ of their leadership pointed out they were issuing out union regalia to their members as a token of appreciation on yearly basis. Secondly they suggested that they were giving the families of their member's funeral assistance amounting to $\$ 300.00$ in the event that the principal member dies. Upon retirement the union was also giving its members $\$ 100.00$ to assist in the event of relocation or any other pressing needs. Respondents went to explain the in the event of retirement the obligation to ensure full retirement packages was the mandate of the union and not the individual member. To ZUCWU members these were membership drive strategies. However some ZUCWU respondents $(56 \%)$ indicated that they could not work with a broke entity. $49 \%$ as depicted by table 2 above of the total respondents felt that collaboration was an issue given that the union leaders were affiliated to different political parties with different ideologies hence making them oil and water.

39.2 of the total respondents felt that collaboration was possible. They cited the 2014 collaboration which was partially successful up to the negotiation stage but was hampered by politicking and inability to compromise by "some" and not "all" union officials from different perspectives.

\subsection{Inter Union Rivalry Adversely Affecting Workers}

$78.3 \%$ respondents pointed out that inter-union rivalry was adversely affecting workers, while $19.5 \%$ respondents felt that inter-union rivalry had no effect on workers, with only $1.9 \%$ neutral. This was also supported by $64.6 \%$ respondents who indicated that unions are failing to deliver in the best interest of workers, despite $23.5 \%$ who felt unions are trying their level best. Resultantly from such responses the researchers through interviews sought clarification from respondents on the adverse effects of union rivalry on effective employee representation.

78.3\% respondents representing both ZRUWU and ZUCWU acknowledged that union rivalry has an adverse effect on effective worker representation which affects shop floor industrial relations. From the findings 5 key problems were identified as serious issues affecting workers which was as a result of inter union rivalry. The $78.3 \%$ respondents 
identified that the employer unilaterally changed the medical aid provision which was initially agreed by Unions and Council, Management. They explained that the employer used to contribute $75 \%$ but switched to $50 \%$ covering only 3 dependents, yet traditionally the number of dependents was the beneficiary's prerogative. Employees from grades 1-7 (ordinary and general employees) were further pushed to utilise public medical facilities while management (grade 8-12) were given private hospitals and the executive (grade 13-16) were given no limit. The respondents explained that given the absence of workers committee management had a free reign hence adversely affecting shop-floor industrial relation.

Secondly $60.6 \%$ of the respondents identified a paradigm shift by management on leave provision, which they felt was further exacerbated by union rivalry resulting union members adversely affected. They explained that given massive contract termination employees failed to go on their annual leave and their days could be paid on cash and had no limit since the problem was employer motivated. The respondents pointed out that with effect from 2015 management created a limit of 90 days, without consulting any union. This affected people who had worked for more than 3 years and on holidays motivated by the pending cash in-leau of leave. Thus with no workers committee in place any agreement made by individual union had no force to enforce the agreement.

Equally $78.3 \%$ of the respondents pointed out that management unilaterally reduced people's salaries which are a case that is still under conciliation but initially workers had negotiated to solve the problem in-house but given the absence of a works council no meaningful engagement is taking place. $50 \%$ of the respondents pointed out that political affiliation was another key challenge threatening the unions and affecting workers in general. The respondents agreed that union officials were channelling much energy on party politics ignoring key issues and strategic issues affecting workers. They pointed out at both ZUCWU and ZRUWU had roots in politics hence at times their differences and failure to collaborate on union business was politically motivated. All union members that participated in the study agreed that workers are affected because of failure by unions to agree on selecting members to sit in the work's council. They $(78.3 \%)$ respondents acknowledged that when pushing an agenda as a union and not a works' council whatever is agreed is non-statutory and neither legally binding thus defeating the whole purpose to engage management, obviously admitting that this affects effective worker representation.

However 19.5 respondents felt that inter-union rivalry was not bad but healthy in perfect completion. The respondents suggested that at times union rivalry resulted in unions becoming more responsible through giving out benefits of all kinds. They blamed management through sponsoring rebels to de-campaign unions. $20 \%$ of these respondents pointed out that unions were also affected by people who are not union members but waited to enjoy the benefits negotiated by unions without paying union subscriptions. These they referred to as, "free-riders". ZUCWU (10\%) senior respondents reiterated that such employees were a major drawback towards the achievement of $50 \%$ majority as they waited to reap the benefits drawn by unions.

\subsection{Analysis of Findings and Conclusions}

From the discussion above it is clear that union rivalry affects workers who suffer because of union officials in power struggles. While it is clear that unions may be politically affiliated, in our view there is nothing wrong with this but when they lose focus, they then fail to justify their existence. Unions through shop stewards exist at the grass root to promote, protect and improve the economic, the social and the political interests of their members both in the workplaces and in society [11]. These should be the interest of workers and not unions per-se. The performance of trade unions is closely bound up with questions of identity, but the identity showed reveal benefits to union members. If it fails to do so then there is no basis for unionisation [4]. There is little doubt that politics matters to unions; the strength of a union is a product of membership, and actual 'clout at the bargaining table and in politics [10]. But while this is key unions should not lose focus of pursing their member's interest which then results in the maintenance of harmonious industrial relations.

Employers can easily ignore a weak union as it hardly represents the workers [13]. They went on to explain that the agreement with such a union will hardly be honoured by management a situation that was revealed equally by respondents from both unions. The free riders concept which typified the council may prove failure by unions to maintain effective shop-floor industrial relations by effectively representing worker interest. Management given such a window of opportunity end up making decisions that are go uncontested. The paper concludes that the absence of a workers committee to represent workers in the works council is affecting workers grossly hence defying logic of the union existence. This may explain why the unions are failing to garner membership so as to gain $50 \%$ majority. Trade unions, worldwide, are experiencing difficulties on many counts in general and retention of quality membership in particular. There has been substantial erosion both in membership as well as bargaining power of unions [13]. The paper maintains that the identified trend by the author above is heralded through the experience of the 3 trade unions who have lost tremendously legitimacy as evidenced by free managerial will and prerogatives. For many industrial relations theories, the founding principle of trade unionism resides in the existence of objective interests shared by members of the workforce [12]. The emergence and longevity of collective organizations flows from the strength and significance of these interests [12]. Union rivalry in this regard tempers against such interest and management take advantage of this situation which therefore create disharmony and discord thus grossly affecting unionism. The task of union organizations therefore is first to identify and interpret these collective interests and then to organize, in accordance with the circumstances, the appropriate forms of mediation in the relation to the common interest, a situation that is lacking hence challenging union legimacy and adversely affecting 
shop-floor industrial relations.

The paper concludes by identifying that union rivalry is mainly exacerbated by the political alliance of trade unions and political protagonists. This makes the unions to lose vision and focus towards achieving the sole purpose of their existence. At the end unions spend a lot of time fighting each other, painting each other in the darkest colour. This equally affects union density where potential members see no value addition in joining unions. Union rivalry creates an avenue for union fragmentation which management capitalise on to maintain a divide and rule tactic. Workers are therefore left exposed as unions will be focusing on power games and not bread and butter issues. Given the intensity of competition for legitimacy, acceptance and recognition clear battle lines between unions are created and at the end of the day workers wail and lament while management always have the last laugh.

\section{Recommendations}

Based on the discussion above the paper therefore recommends that the unions while sorting out the $50 \%$ majority issue to form a worker's committee for the purposes of addressing pressing employee needs and benefit all their members they have to agree on a pro-rotor system to select an interim workers committee that will represent the needs of employees through a work's council. Equally while politically affiliated all the unions should shun politicking particularly on issues that concerns workers, alliances can be forged to champion the employee agenda, thus channelling more energy on worker issues than party politics. Notably the unions should have a unit of purpose for the sake of their members. Since there are members who are non union members but who benefit from union negotiations all unions should form an Employment Council which will agree on levying these members and distribute the proceeds on pro-rotor basis.

\section{References}

[1] Macdonald, V. (2014). Trade Union Rivalry is Causing Concern. Times of Malta, pp. 5-6, 8 March.
[2] Singh, P. \& Kumar, N. (2011). Employee Relations. NewDelphi: Dorling Kindersley(India) Pvt.Ltd.

[3] Gupta, A. \& Gupta, N. (2013). The 21st Century Trade Union Challenges in India. Journal of Accounting and Marketing, pp. $8-21$.

[4] Katsourides, Y. (2013). Political Parties and Trade Unions in Cyprus. Hellenic Observatory Eroupean Institute, London.

[5] Budeli, M. (2012). Trade Unionism and Politics in Africa: the South African experience. The Comparative and International Law Journal of Southern Africa, pp. 454-481, 2012.

[6] Wright, C. F. (2011). What role for Trade Unions in future workplace relations? Acas Future of Workplace Relations, University of Cambridge.

[7] Philippe, S. (2008). The Changing Politics of Organised Interest. West European Politics, Vol 31(3), pp. 195-210.

[8] Hyman, R. \& Gumbrell-McCormick, R. (2010). Trade unios,n politics and parties: is a new configeration possible? European Review of Labour and Research, Vol. 16 No3, pp. 315-331.

[9] Harcourt, M. (2014). US union revival, minority unionism and inter-union conflict. Journal Of Industrial Relations, pp. 653671.

[10] Pawlenko, K. D. (2006). Re-evaluating Inter-Union Competition. UPA Journal of Labour and Emploment Law, Vol 8(3), pp. 651-606.

[11] Ayantunji, O. I. \& Ayantunji, M. M. (2016). An Ecclectic Approach for the Training of the Shop Stewards in the Industrial Relations System in Nigeria. International Journal of Academic Research in Economics and Management Sciences, Vol 2(3), pp. 34-56.

[12] Dofour, C. (2010). The legitimacy of collective actions and trade union renewal. European Review of Labour and Research, pp. 351-367.

[13] Rajesh, S. \& Manoj, K. P. (2014). Politicization Of Trade Unions and Challenges to Industrial Relations in India:A Study with a focus on Nothern Kerala. International Journal of Business and Administration Research Review, Vol 1(2), pp. 78-96. 